\title{
Glioblastoma multiforme in a patient with common variable immunodeficiency and multiple malignancies - a case report
}

\section{Glejak wielopostaciowy mózgu u chorej z pospolitym zmiennym niedoborem odporności i mnogimi nowotworami - opis przypadku}

\author{
Michał Larysz'1 Rafał Becht², Michat Falco ${ }^{3}$, Przemysław Nowacki ${ }^{4}$, Ireneusz Kojder ${ }^{5} \bowtie$ \\ ${ }^{1}$ Pomorski Uniwersytet Medyczny w Szczecinie, Klinika Neurochirurgii i Neurochirurgii Dziecięcej, ul. Unii Lubelskiej 1, 71-252 Szczecin \\ 2 Pomorski Uniwersytet Medyczny w Szczecinie, Oddział Kliniczny Onkologii, Chemioterapii i Immunoterapii Nowotworów, ul. Unii Lubelskiej 1, 71-252 Szczecin \\ ${ }^{3}$ Pomorski Uniwersytet Medyczny w Szczecinie, Oddział Kliniczny Radioterapii, Zachodniopomorskie Centrum Onkologii, ul. Strzałowska 22, 71-730 Szczecin \\ ${ }^{4}$ Pomorski Uniwersytet Medyczny w Szczecinie, Katedra i Klinika Neurologii, ul. Unii Lubelskiej 1, 71-252 Szczecin \\ ${ }^{5}$ Pomorski Uniwersytet Medyczny w Szczecinie, Zakład Neurokognitywistyki Stosowanej, ul. Unii Lubelskiej 1, 71-252 Szczecin \\ $\triangle$ neuroch@pum.edu.pl
}

\section{ABSTRACT}

A case of glioblastoma multiforme in female patient suffering from common variable immune deficiency syndrome is presented. The patient with history of previously treated due to breast carcinoma and ovarian cancer. The patient underwent craniotomy

\section{ABSTRAKT}

W artykule zaprezentowano przypadek 53-letniej kobiety z glejakiem wielopostaciowym, która leczona była uprzednio z powodu raka przydatków oraz raka przewodowego piersi. Chorą leczono z powodu pospolitego zmiennego niedoboru twice followed by radiotherapy and chemotherapy with temozolomide and finally died after 11 months.

Keywords: common variable immune deficiency; glioblastoma multiforme.

\section{INTRODUCTION}

Primary immunodeficiencies (PIDs) are rare inherited disorders of the immune system. Clinical manifestations of PID include a broad spectrum of symptoms from mild, persistent infections to severe septic conditions. They may also be manifested by autoimmune diseases affecting multiple organs, as well as the increased risk of developing malignant tumours.

Most commonly, primary immunodeficiencies concern humoral immunity and are associated with deficiency of antibodies. Common variable immune deficiency (CVID), depending on the ethnicity of the population, affects 1 in 10,000-50,000 subjects and is diagnosed with a similar frequency in women and men.

Clinical symptoms of CVID generally develop between 20 and 40 years of age, but some cases may be diagnosed in subjects aged 50 and older. Patients with CVID are susceptible to frequent persistent and recurrent infections with bacteria and viruses affecting various organs. Observational studies have shown that patients with CVID are at risk of developing malignant tumours, mainly lymphoid hyperplasia and gastrointestinal tract malignancies $[1,2,3]$.

The paper presents the case of a female patient with CVID, diagnosed with 3 malignant neoplasms, including glioblastoma multiforme, which has not been previously reported. odporności podawaniem immunoglobuliny. Poddana 2-krotnie resekcji guza mózgu i radioterapii oraz chemioterapii (temozolamid), zmarła po 11 miesiącach.

Słowa kluczowe: pospolity zmienny niedobór odporności; glejak wielopostaciowy.

\section{CASE REPORT}

A female patient, J.T., aged 53, was diagnosed with CVID in 2010 (based on frequent infections of the upper and lower respiratory system and decreased levels of immunoglobulins) and was treated in 2004 due to right ovary cancer with metastasis to the left ovary. Because of the ovarian cancer the patient had undergone hysterectomy with adnexectomy and received 6 courses of chemotherapy. In 2011 she was diagnosed with cancer of the right breast; carcinoma ductale invasivum grade $2 \mathrm{~B}-\mathrm{R}+$ carcinoma intraductale $\mathrm{G} 3$ (comedocarcinoma) histopathological stage T1cNoMo. For this reason the patient underwent right breast quadrantectomy, radiotherapy and hormonal therapy with Tamoxifen. From the diagnosis of CVID the patient received intravenous immunoglobulins every 21 days.

In 2015 the patient received treatment at the Department of Neurosurgery, Pomeranian Medical University in Szczecin in Poland due to the diagnosed tumour in the right occipital lobe, manifested by two foci situated close to each other. Before the diagnosis the patient suffered from non-specific paresthesia in both arms, vision disorders, recurring headaches and paroxysmal changes in the electroencephalography, but no symptoms were found in contrast-enhanced computed tomography. Magnetic resonance imaging revealed 


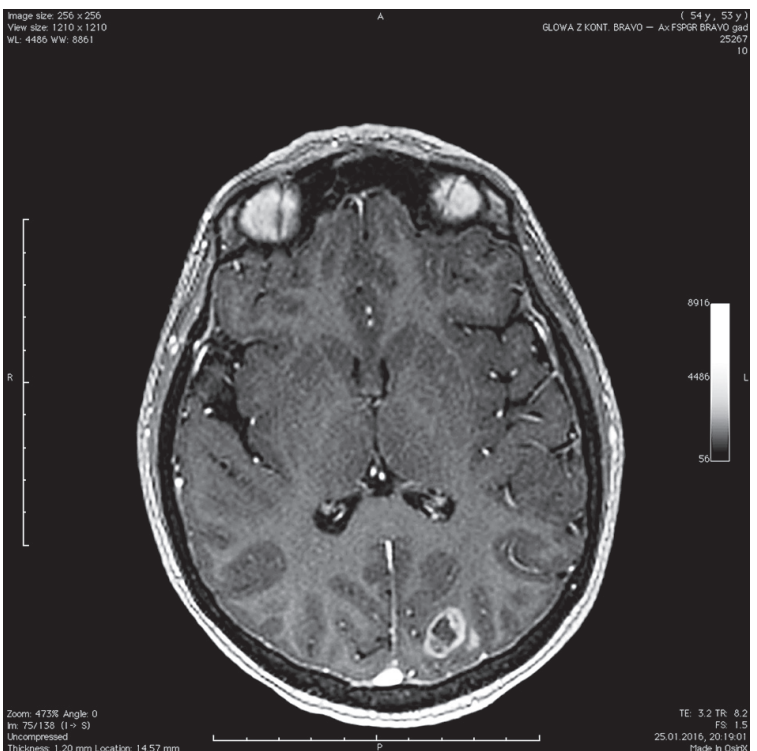

FIGURE 1. Brain MRI showing the lesion of left occipital lobe

unclear lesions in the left occipital lobe (Fig. 1). Because of the positive oncologic history, metastatic lesions were suspected at first.

The patient underwent tumour resection by neuronavigation-guided craniotomy. The postoperative course was uneventful except for a moderate limitation of the visual field. Pathological examination revealed anatomical structures typical for glioblastoma multiforme (Fig. 2). After craniotomy the patient
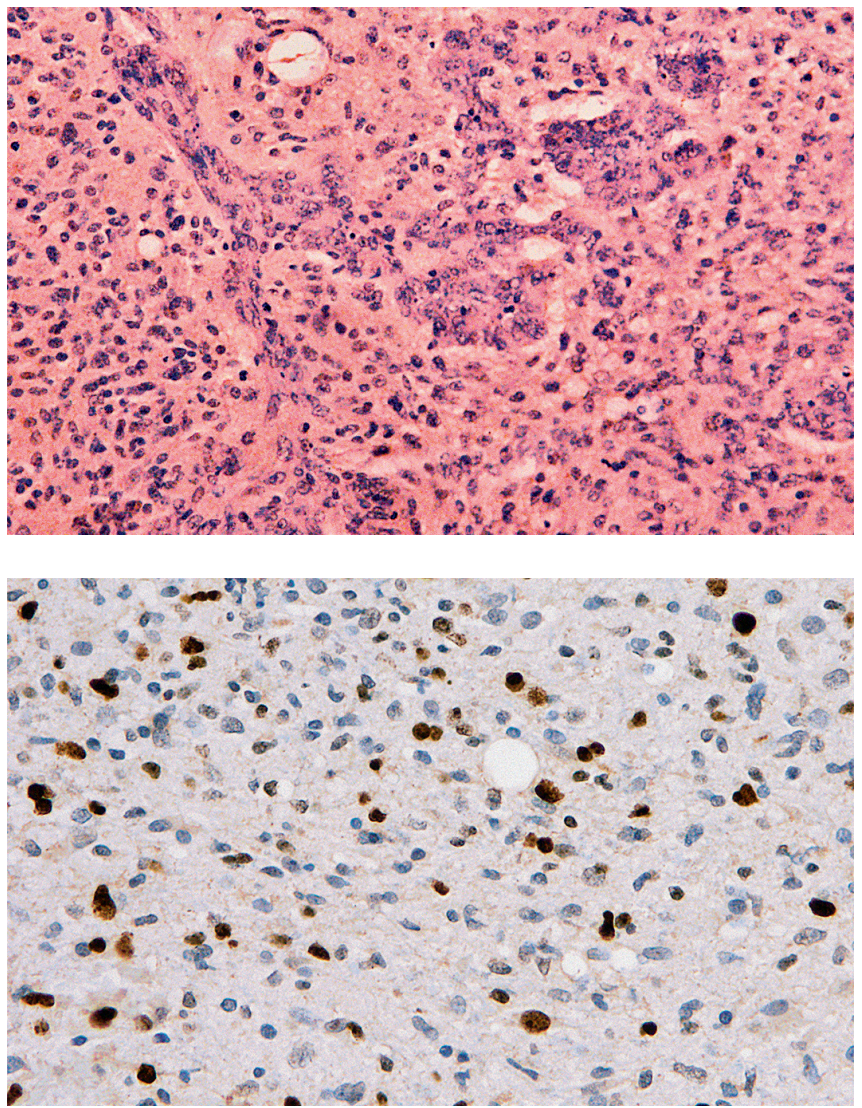

was further treated with radiotherapy (6o Gy) and chemotherapy (temozolomide), which were tolerated well.

Six months later the patient's general status deteriorated; quantitative disorders of consciousness and right-side paresis intensified. Magnetic resonance imaging revealed brain tumour recurrence near the site of the previous tumour removal, which was unobserved in postoperative follow-up examination 6 weeks earlier (Fig. 3). Cytoreductive surgery was performed (18.09.2016) and no further radiotherapy or chemotherapy were used. The patient was discharged in relatively good health.

Three weeks later the patient's conditions deteriorated again, and an nuclear magnetic resonance scan revealed increased oedema and tumour size. The patient was not qualified for causative treatment and the administration of immunoglobulins was abandoned. The patient was transferred to a hospice and died there.

\section{DISCUSSION}

Although the genetic instability of lymphocytes and continuous stimulation and proliferation of immune cells in the course of recurrent infections promote the development of metastases, breast and ovarian cancers or glioblastoma multiforme (GBM) are not pathologies characteristic for CVID. Common variable immune deficiency is more commonly associated with malignancies of the haematopoietic system and much less frequently reported solid tumours, primarily gastric cancer [3].
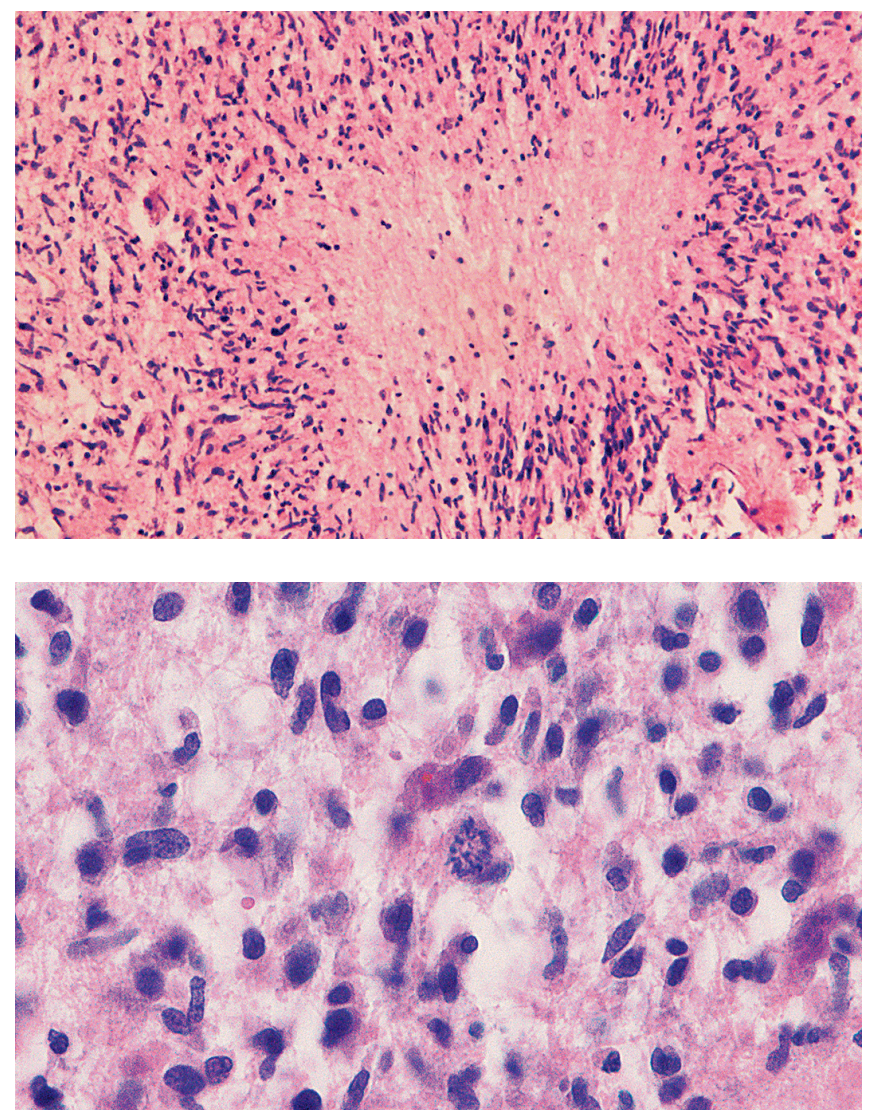

FIGURE 2. Pathological image of glioblastoma multiforme tissue removed from brain of common variable immune deficiency patient 
a)

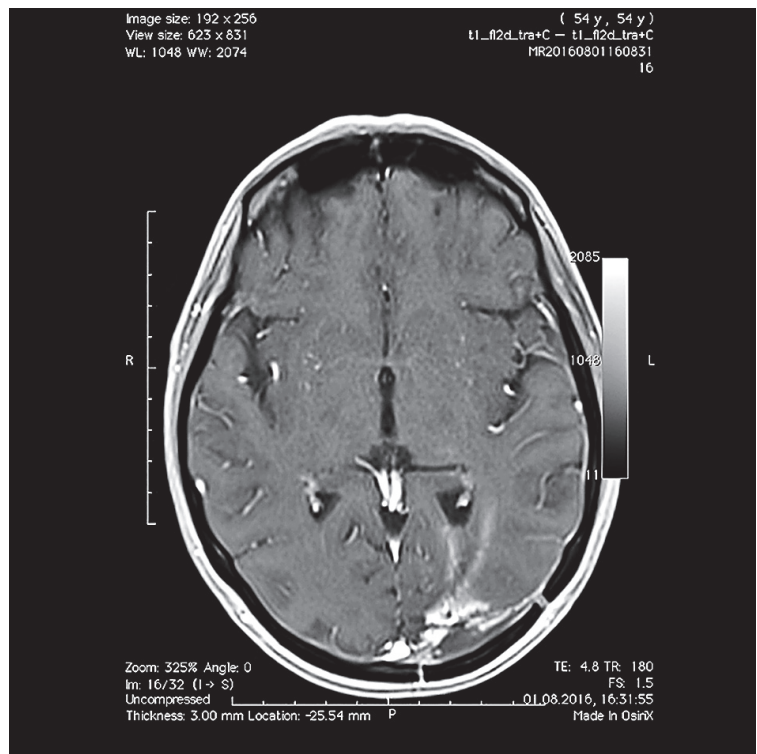

b)

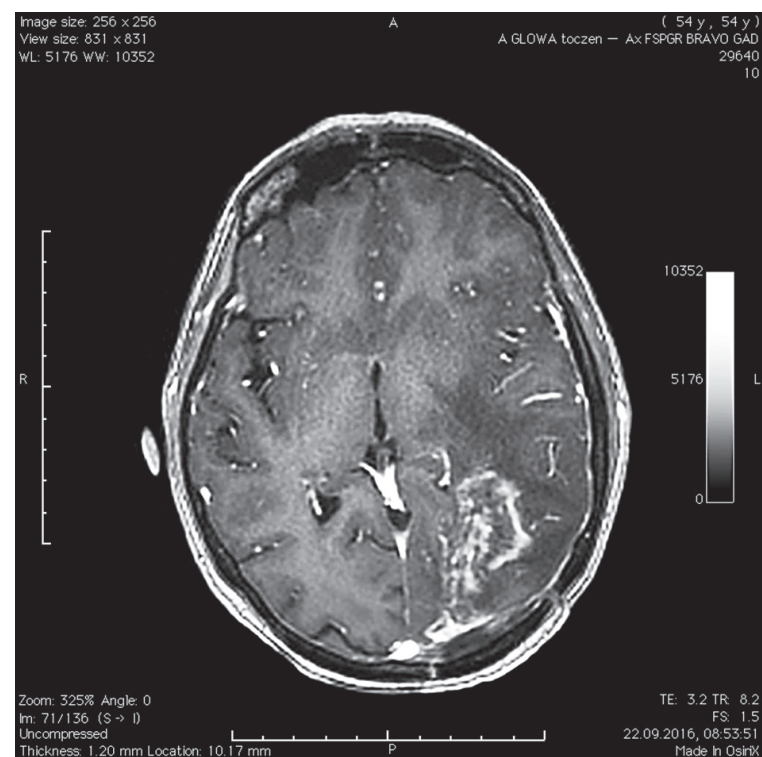

FIGURE 3. Postoperative brain MRI showing: a) postoperative changes (1 month); b) recidival tumour seen (6 months)

TABLE 1. Published common variable immune deficiency cases with accompanied malignant tumours

\begin{tabular}{|c|c|c|}
\hline Malignancy type & No. cases & References \\
\hline Breast cancer & 9 & \multirow{15}{*}{ Resnick et al. [4] } \\
\hline Gastric cancer & 3 & \\
\hline Melanoma & 3 & \\
\hline Malignancy of unknown & primary 3 & \\
\hline Colon cancer & 2 & \\
\hline Lung cancer & 2 & \\
\hline Oral cancer & 2 & \\
\hline Skin cancer & 2 & \\
\hline Hepatic carcinoid tumour & 1 & \\
\hline $\begin{array}{l}\text { Colorectal, prostate } \\
\text { cancer }\end{array}$ & 1 & \\
\hline Prostate, skin cancer & 1 & \\
\hline Thyroid cancer & 1 & \\
\hline Vaginal cancer & 1 & \\
\hline Ovarian cancer & 1 & \\
\hline Oesophageal cancer & 1 & \\
\hline Hodgkin's disease & 1 & \multirow{4}{*}{ López-Rocha et al. [5] } \\
\hline $\begin{array}{l}\text { Pancreatic } \\
\text { neuroendocrine tumour }\end{array}$ & 1 & \\
\hline $\begin{array}{l}\text { Chronic myeloid } \\
\text { leukaemia }\end{array}$ & 1 & \\
\hline Papillary thyroid cancer & 1 & \\
\hline Uterine adenocarcinoma & \multirow{4}{*}{1} & \multirow{4}{*}{ Todorovic et al. [6] } \\
\hline Basal cell carcinoma & & \\
\hline $\begin{array}{l}\text { Diffuse large B cell } \\
\text { lymphoma }\end{array}$ & & \\
\hline $\begin{array}{l}\text { Colorectal } \\
\text { adenocarcinoma }\end{array}$ & & \\
\hline Ovarian cancer & \multirow{3}{*}{1} & \multirow{3}{*}{ Authors } \\
\hline Ductal breast cancer & & \\
\hline $\begin{array}{l}\text { Brain glioblastoma } \\
\text { multiforme }\end{array}$ & & \\
\hline
\end{tabular}

The reported case is interesting because of the rapid progression of malignant lesions in the central nervous system. The median survival of patients with GBM who undergo complete resection, radiotherapy and chemotherapy is approx. 1 year.

Resnick et al. presented a metaanalysis of 473 patients with CVID treated at the Mount Sinai Medical Centre in 1974-2012 [4]. Malignancy developed in 33 of these patients (Table 1).

In another study López-Rocha et al. analysed 23 patients with CVID, and malignancy developed in 4 of them: Hodgkin's disease (1), pancreatic neuroendocrine tumour (1), chronic myeloid leukaemia (1), and papillary thyroid cancer (1) [5].

Todorovic et al. reported the case of a 55-year-old woman with a previous history of malignancies - uterine adenocarcinoma (at age 35), basal cell carcinoma, diffuse large B cell lymphoma and colorectal adenocarcinoma [6].

Interestingly, the professional literature does not provide information on the coexistence of CVID, GBM and multiple solid tumours, and to our knowledge this is the first case report regarding this subject. Our patient at first developed cancer (ovarian cancer), which recurred 7 years later, and was diagnosed with GBM after another 5 years. After the diagnosis of GBM the patient lived for 11 months, which does not differ substantially from the reported average survival time. However, the short remission time between individual therapeutic interventions is noteworthy, although it is clinically observed in some patients, including those without diagnosed CVID.

\section{REFERENCES}

1. Chapel $\mathrm{H}$, Cunningham-Rundles $\mathrm{Ch}$. Update in understanding common variable immunodeficiency disorders (CVIDs) and the management of patients with these conditions. Br J Haematol 2009;145(6):709-27.

2. Abbott JK, Gelfand EW. Common variable immunodeficiency: diagnosis, management, and treatment. Immunol Allergy Clin North Am 2015;35: 637-58. 
3. Resnick ES, Cunningham-Rundles Ch. The many faces of the clinical picture of common variable immune deficiency. Curr Opin Allergy Clin Immunol 2012;12(6):595-601.

4. Resnick ES, Moshier EL, Godbold JH, Cunningham-Rundles Ch. Morbidity and mortality in CVID. Blood 2012;119(7):1650-7. doi: 10.1182/blood2011-09-377945.
5. López-Rocha E, Rodríguez-Mireles K, Segura-Méndez NH, YamazakiNakashimada MA. Malignancies in adult patients with common variable immunodeficiency. Rev Alerg Mex 2015;62(1):22-7.

6. Todorovic M, Balint B, Andjelic B, Mihaljevic B. Multiple malignancies in a female patient with common variable immunodeficiency syndrome. Singapore Med J 2014;55(10):e162-4. 